\title{
Irrigation Level Management and Mulching on Onion (Allium cepa L.) Yield and WUE in Western Ethiopia
}

\author{
Tasisa Temesgen \\ School of Natural Resource Management and Environmental Sciences, Haramaya University, Ethiopia
}

How to cite this paper: Temesgen, T. (2018) Irrigation Level Management and Mulching on Onion (Allium cepa L.) Yield and WUE in Western Ethiopia. The Journal of the Science of Food and Agriculture, 2(3), 45-56.

http://dx.doi.org/10.26855/jsfa.2018.03.001

Corresponding author: Tasisa Temesgen, School of Natural Resource Management and Environmental Sciences, Haramaya University, Ethiopia

E-mail: tasisatemesgen@gmail.com

Tel: +251-912362787

\begin{abstract}
In the context of improving Water Use Efficiency, there is interest in deficit irrigation, which provides a means of reducing water consumption while minimizing adverse effects on yield. A field experiment was conducted at Ambo Agricultural Research Center, Ethiopia during 2017 dry season. The objective was determining effects of irrigation levels and mulching material on yield and Water Use Efficiency of Onion. The experimental design was in RCBD with three replications. The deficit irrigation levels $100 \%, 80 \%, 70 \%, 60 \%$ and $50 \%$ ETc used with the three mulching no mulch, straw and plastic mulch were used. The results revealed that the maximum yield of 47.25 ton ha- 1 was recorded from $100 \%$ ETc with plastic mulch; whereas the minimum yield of 18.2 ton ha-1 was recorded from 50\% ETc with no mulch. Higher Crop Water Use Efficiency and Irrigation Water Use Efficiency of about 12.75 and 7.63 ha-1mm-1 was obtained from $70 \%$ ETc with plastic mulch respectively. With $70 \%$ ETc and plastic mulch the water saved, yield reduction and Crop Water Use Efficiency were $109.5 \mathrm{~mm}, 12.65 \%$ and $12.75 \mathrm{~kg}$ ha-1 $\mathrm{mm}-1$ respectively. Considering water saved and maximum yield, irrigation water application at $70 \%$ irrigation application levels and plastic mulch could be interested. The present study suggests that, in water scarce area, farming community can adopt deficit irrigation level with $70 \%$ ETc under plastic mulch.
\end{abstract}

Keywords

Deficit irrigation, Drip irrigation, Mulches, Yield, WUE

\section{Introduction}

In the context of improving water productivity, there is growing interest in deficit irrigation, a practice where by water supply is reduced below maximum level and mild stress is allowed with minimum effect on yield (Dirirsa et al., 2017 and Mekonen, 2011). Regulated deficit irrigation is water saving technology that is relatively inexpensive and easy to implement (Tilahun et al., 2004 and Temesgen et al., 2018). Under conditions of water stress and drought, deficit irrigation can lead greater water use efficiency by maximizing yield per unit of water used (Temesgen et al., 2018). 
The main constraints that contributed to lower productivity of onion in Ethiopia are type of cultivar, traditional and backward production methods and lack of proper irrigation methods, erratic rainfall, inadequate inputs, and many other problems (Awulachew et al., 2007 and Nigatu, 2008).

Understanding the yield response factor of onion with deficit irrigation throughout the growing season is important for optimal scheduling of the limited water supply and for better crop management practice related to soil moisture. Therefore, this study was initiated in view of the existing problem to determine the effects of deficit irrigation levels and mulching materials on yield and evaluate water use efficiency of drip-irrigated onion under deficit irrigation levels and mulching materials.

\section{Materials and methods}

\subsection{Description of the Study Area}

The experiment was carried at Ambo Agricultural Research Center, in Oromia, Ethiopia. The Research Center is located at about $115 \mathrm{~km}$ west of Addis Ababa, at an altitude of 2225 masl. It is located at $08^{\circ} 57^{\prime \prime N}$ latitude and $37^{\circ} 52^{\prime \prime E}$ longitude (Figure 1). The area has a warm humid climate with mean monthly minimum, maximum temperatures and average total annual rainfall of about $10.3^{\circ} \mathrm{C}, 26.4^{\circ} \mathrm{C}$ and $1036 \mathrm{~mm}$ respectively.

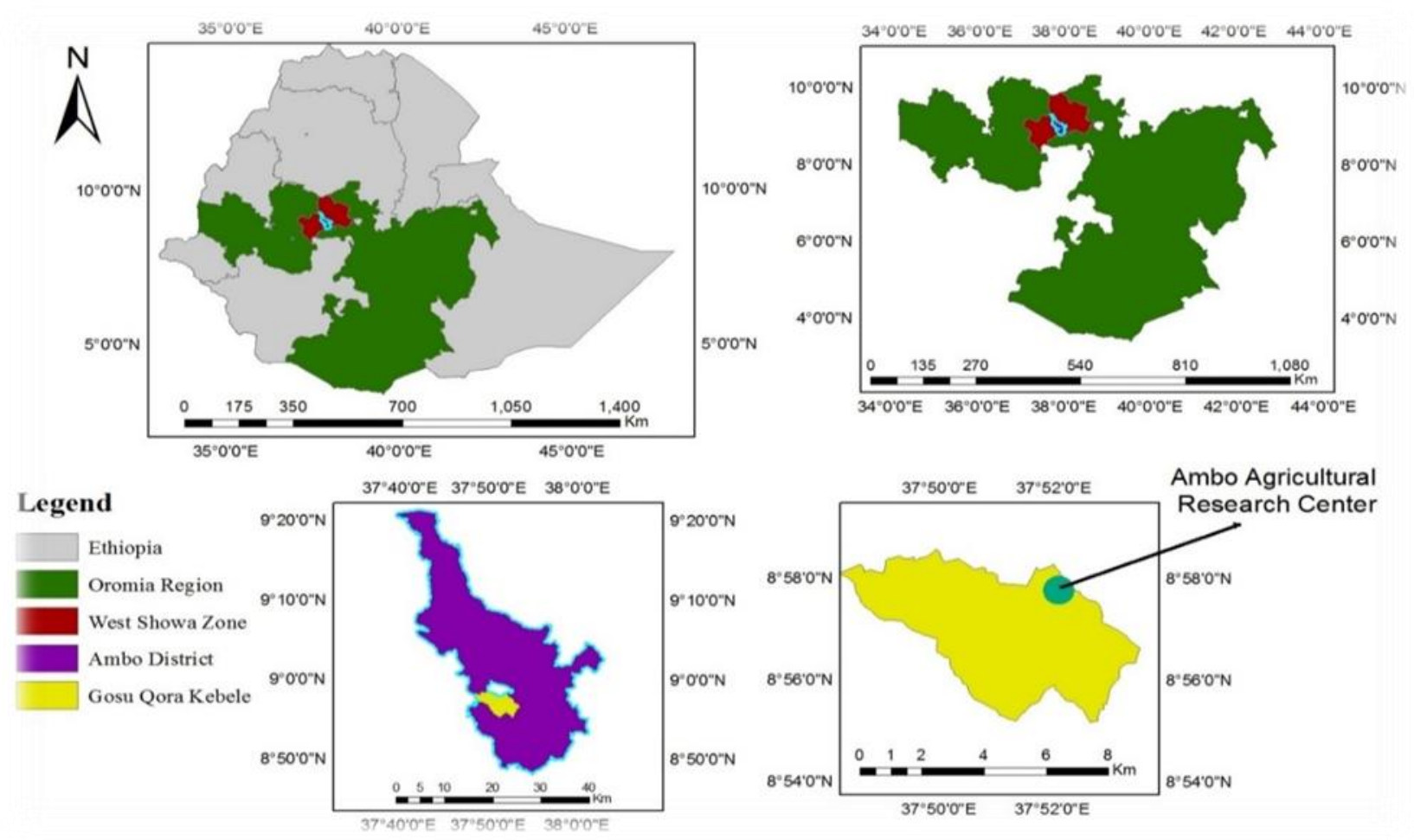

Figure 1. Location map of Ambo Agricultural Research Center

\subsection{Experimental Design and Treatments}

The experimental design was in RCBD with three replications. The Treatments include four deficit irrigation applications $(80 \%$ ETc, $70 \%$ ETc, $60 \%$ ETc and 50\% ETc) and a full irrigation application $(100 \%$ ETc) and three mulching material No Mulch (NM), Straw Mulch (SM) and Plastic Mulch (PM) (Figure 2). Depending up on irrigation level value there is no standard value put but different researcher use different values. The design of the level was in line with Heidari (2012) he used the same level of deficit for the same crop type. Control irrigation implies the amount of irrigation water applied in accordance with the computed crop water requirement with the aid of CROPWAT program. 
Table 1. Details of Experimental Treatments

\begin{tabular}{cl}
\hline Treatments & \multicolumn{1}{c}{ Explanation } \\
\hline T1 & $100 \%$ ETc, no mulch \\
T2 & $100 \%$ ETc, straw mulch \\
T3 & $100 \%$ ETc, plastic mulch \\
T4 & $80 \%$ ETc, no mulch \\
T5 & $80 \%$ ETc, straw mulch \\
T7 & $80 \%$ ETc, plastic mulch \\
T8 & $70 \%$ ETc, no mulch \\
T9 & $70 \%$ ETc, straw mulch \\
T10 & $70 \%$ ETc, plastic mulch \\
T11 & $60 \%$ ETc, no mulch \\
T13 & $60 \%$ ETc, straw mulch \\
T14 & $60 \%$ ETc, plastic mulch \\
T15 & $50 \%$ ETc, no mulch \\
\end{tabular}

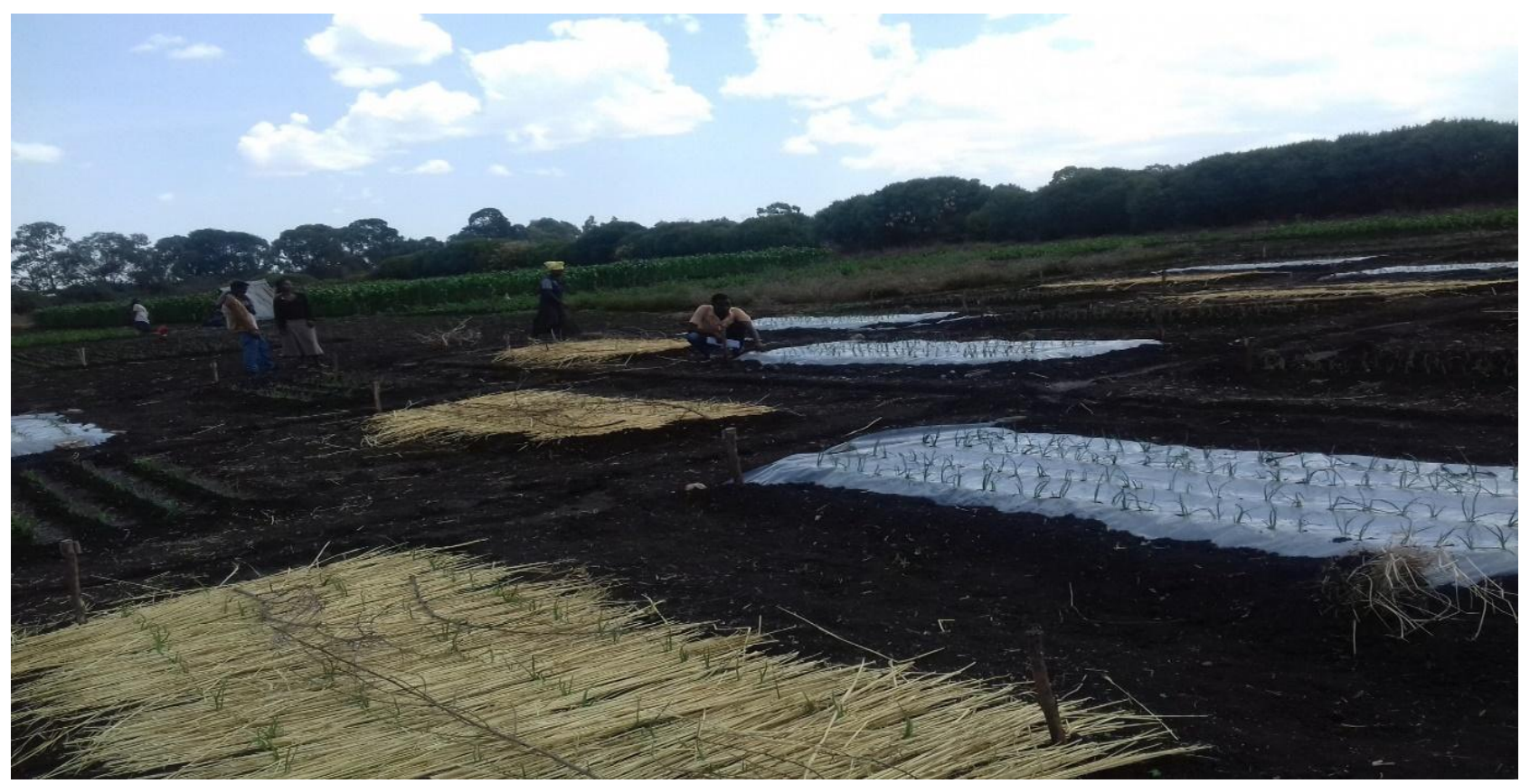

Figure 2. Pictures of No Mulch (NM), Straw Mulch (SM) and Plastic Mulch (PM) of treatments

\subsection{Experimental Procedures}

\subsubsection{Land preparation and nursery management}

The field for nursery bed was ploughed and harrowed to bring it to a fine tilth and a seed bed was prepared. Adama onion variety called Ambo Agricultural Research Centre was used for the study. The seeds of this cultivar were sown on nursery bed and after sowing; the beds were covered with dry grass mulch until emergence and watered using a watering can. A week before transplanting, water supply to the nursery seedbed was reduced in order to harden the seedlings to reduce transplanting shock. Before transplanting, the seedlings were watered to enhance easy uprooting and to prevent root damage.

\subsubsection{Preparation of the experimental plots}

The experimental field plot was ploughed using tractor, leveled and made ready by dividing the field in to 45 plots for transplanting. The plot size was $3.5 \mathrm{~m}$ x $3.9 \mathrm{~m}=13.65 \mathrm{~m}^{2}$, with $1 \mathrm{~m}$ spacing between adjacent plot and $1.5 \mathrm{~m}$ between replications. A plot consisted of five rows with a row length of $3.9 \mathrm{~m}$. The seedlings were transplanted to field plots on 
the first week of April 2017. Transplanting was done late in the afternoon to reduce the risk of poor establishment. More number of seedlings than that required for transplanting was raised so that vigorous, strong and healthy ones were selected. The spacing between plants within a row and between plot were $30 \mathrm{~cm}$ and $70 \mathrm{~cm}$, respectively, with a total of 5 rows per plot. A row consists of 13 plants and a plot 65 plants. The net harvesting area of a plot was $3.3 \mathrm{~m} \mathrm{by} 2.1 \mathrm{~m}$ $\left(6.93 \mathrm{~m}^{2}\right)$. The first plant was planted $15 \mathrm{~cm}$ from the border row in each plot.

\subsubsection{Application of mulches}

Two types of mulching materials, namely plastic and straw mulch were used for the experiment. Plastic mulches were applied before transplanting of onion seedlings by making small holes at the desired intra row spacing and the seedlings were transplanted. White (transparent) plastic film that allow sunlight to pass through in to the soil and having typical characteristics of 20-25 microns or 80-100 gauge thick wide was used. Transparent plastic mulch was selected because it provides more yields than black plastic mulch and it is characterized by occurrence of higher soil temperature that it permits early germination, bulbing, increases water use efficiency, and harvesting than black plastic mulch. However, straw mulches were applied immediately after transplanting of seedlings. For the straw mulches, dried vetivar grass which is easily available in the area was chopped to about $10-15 \mathrm{~cm}$ before it was used as mulch. Generally, mulching practice was made as 6 ton/ha for straw mulch and as the area of the plot in plastic mulch.

\subsubsection{Drip irrigation system installation}

Drip irrigation system was used for applying irrigation water. Drip system consists of Polyvinyl Chloride main lines, sub main and laterals. The plots were leveled manually to create uniform plots within the given treatment. The drip laterals were installed in such a way that the spacing between rows is equal to that between the lateral and spacing between plants is equal to emitters spacing. There were 45 plots laid out in $3.9 \mathrm{~m}$ length, five laterals per plot. Hence, each plot consisted of five drip lateral lines; each lateral has $3.9 \mathrm{~m}$ length with 13 emitters, so that each emitter drops water to a single plant. The water from the source was collected in a water tanker of 2000 liters capacity, which was placed at a height of $2 \mathrm{~m}$ above the ground surface to supply the required irrigation water to a block of experimental field. The water distribution system components (main line) were laid and connected to the water container and to the individual drip lines. The drip lines (laterals) of $12 \mathrm{~mm}$ diameter were unrolled and laid along the crop rows and each lateral served one row of crop. The end of the laterals and the main lines were closed with end cups to avoid direct soil contact and thus prevent clogging.

\subsubsection{Irrigation water application}

Light irrigations were applied prior to start of treatments applications for ten days. Water applications for full irrigation treatments $(100 \% \mathrm{ETc})$ were based on the estimated crop water requirement calculated over the growing period and those water deficit treatments $80 \%, 70 \%, 60 \%$ and $50 \%$ ETc were imposed as planned. Irrigation frequencies were the same for all treatments under drip irrigation, which was five days interval in the whole growing season. The predetermined amount of irrigation water was based on allowable soil moisture depletion for onion $(p=0.30)$. Soil moisture was monitored before and after irrigation using gravimetric method.

Irrigation interval and depth of irrigation was determined based on allowable soil moisture depletion. The depths of water applied to the field and the soil moisture content before each irrigation events were assumed to be equal to the prescribed irrigation treatment. Irrigation scheduling was determined based on soil moisture monitoring using gravimetric method. Based on regular soil moisture observation, irrigation was applied to onion crop through drip when about $30 \%$ of available soil moisture was depleted from the effective root zone. The root depth of onion can extend up to $1 \mathrm{~m}$ but under irrigation, roots are concentrated mainly in the upper $30 \mathrm{~cm}$ soil depth. Nevertheless, $100 \%$ of the water uptake occurs in the first 0.5 to $1.0 \mathrm{~m}$ soil depth $(\mathrm{drz}=0.5-1.0 \mathrm{~m})$. In this study, the maximum crop root depth was considered as $1.0 \mathrm{~m}$. Soil moisture was monitored during experimental time up to $80 \mathrm{~cm}$ by considering the growth stage of onion. Prior to irrigation, available soil moisture content for all the treatments were measured at 0-20, 20-40, 40-60 and $60-80 \mathrm{~cm}$ soil depths using the gravimetric method. The total depth of water was applied to 1.0 ETc to bring the measured gravimetric soil water content to field capacity level and to other stressed treatment to bring the measured gravimetric soil water content to prescribed soil water after irrigation.

According to Walker (1989), soil moisture depletion at any soil moisture level can be calculated as:

$$
\mathrm{SMD}=\sum\left(\frac{(\text { evfc- }- \text { vi })}{100}\right) \mathrm{Zr}
$$

The depth of water applied through the respectively growth stages of onion at each irrigation interval was calculated by multiplying total available water with the respective root zone and the allowable depletion percentage. Based on this, the 
amount of water applied with one irrigation time at each growth stages for full irrigation (1.0 ETc) treatment was calculated.

\subsection{Soil sampling and analysis}

Table 2. Soil bulk density, water content (at FC and PWP) and total available water

\begin{tabular}{llllllllllll}
\hline $\begin{array}{l}\text { Soil } \\
\text { depth } \\
(\mathrm{cm})\end{array}$ & $\mathrm{pH}$ & $\begin{array}{l}\text { ECe } \\
(\mathrm{dS} / \mathrm{m})\end{array}$ & $\begin{array}{l}\mathrm{FC} \\
(\%)\end{array}$ & $\begin{array}{l}\text { PWP } \\
(\%)\end{array}$ & $\begin{array}{l}\text { Bulk den- } \\
\text { sity } \\
\left.\mathrm{cm}^{-3}\right)\end{array}$ & $\begin{array}{l}(\mathrm{g} \\
(\%)\end{array}$ & $\begin{array}{l}\text { Slay } \\
(\%)\end{array}$ & $\begin{array}{l}\text { Sand } \\
(\%)\end{array}$ & $\begin{array}{l}\text { Textural } \\
\text { class }\end{array}$ & $\begin{array}{l}\text { TAW } \\
\left(\mathrm{mm} \mathrm{m}^{-1}\right)\end{array}$ \\
\hline $0-20$ & 7.83 & 0.21 & 40.45 & 21.53 & 1.09 & 66.1 & 18.1 & 15.9 & Clay & 206.23 \\
$20-40$ & 8.13 & 0.18 & 35.63 & 17.73 & 1.12 & 66.9 & 17.1 & 16 & Clay & 200.48 \\
$40-60$ & 8.01 & 0.18 & 29.73 & 17.70 & 1.13 & 68.3 & 14.4 & 17.3 & Clay & 135.94 \\
\hline
\end{tabular}

The soil samples were taken from top soil to the depth of $60 \mathrm{~cm}$ in $20 \mathrm{~cm}$ interval. The sub-samples were mixed thoroughly, dried at room temperature, ground and sieved through a $2 \mathrm{~mm}$ screen for physicochemical analysis; whereas for OC and total $\mathrm{N}$ determination soil samples were passed through $0.5 \mathrm{~mm}$ sieve. Soil textural analysis was done using disturbed soil samples which were collected from representative location of the field and textural class was determined by using pipette method in laboratory.

The bulk density was determined using undisturbed soil samples which were collected from the field at three depths $(0$ $-20 \mathrm{~cm}, 20-30 \mathrm{~cm}$ and $30-60 \mathrm{~cm}$ ) oven dried for $24 \mathrm{hrs}$ at $105^{\circ} \mathrm{C}$ and weighed for determination of dry weight. The bulk density was then calculated as:

$$
\rho_{b}=\frac{W_{d}}{V_{T}}
$$

Where, $\mathrm{W}_{\mathrm{d}}$ is weight of dry soil and $\mathrm{V}_{\mathrm{T}}$ is total sample volume.

Determination soil moisture parameter is important of monitoring irrigation. Soil moisture at field capacity (FC) and permanent wilting point (PWP) were determined. For this, the soil samples were collected the three depths described above and sun dried, crushed then, soaked in water for one day (24hr). Pressure plate apparatus and pressure membrane apparatus were used for determination of moisture content at FC and PWP. A suction of $-1 / 3$ bar and -15 bar were exerted for FC and PWP, respectively, for this purpose.

Total available water (TAW), theoretically plant available water, is determined as:

$$
\mathrm{TAW}=1000\left(\theta_{\mathrm{FC}}-\theta_{\mathrm{pWP}}\right) \mathrm{Z}_{\mathrm{r}}
$$

Where, TAW is the total available soil water content $(\mathrm{mm}), \theta_{\mathrm{FC}}$ is soil moisture content at field capacity $\left(\mathrm{cm}^{3} / \mathrm{cm}^{3}\right), \theta_{\mathrm{PWP}}$ is soil moisture content at field permanent wilting point $\left(\mathrm{cm}^{3} / \mathrm{cm}^{3}\right), \mathrm{Z}_{\mathrm{r}}$ is crop rooting depth $(\mathrm{m})$ to which TAW is to be calculated.

\subsection{Water productivity}

Crop water productivity (WP) simply refers to the output (example, crop yield or economic return) with respect to water input during production. This mean the output may be expressed either as physical production in kilograms per un it area or economic return in dollars per area. The water input is the amount of water applied to the cropped area per season. In this study crop, water productivity was estimated as the ration of onion bulb yield to net irrigation depth applied to each treatment plot. It is expressed as:

$$
\mathrm{WP}=\frac{\mathrm{Y}}{\mathrm{W}}
$$

Where, $\mathrm{Y}$ is onion bulb yield $(\mathrm{kg} / \mathrm{ha})$ and $\mathrm{W}$ is irrigation depth applied during the season $\left(\mathrm{m}^{3} / \mathrm{ha}\right)$.

\subsubsection{Crop data collection}

The Crop data was collected from the middle rows in order to avoid border effects. The plants were picked at random carefully from middle three rows by avoiding one plant from starting and ending of three middle rows. Data regarding different components of growth yield and yield components were recorded. These data include among others:

Weight of bulb (single onion bulb weighed): The mean of weights of the bulb for each onion bulb taken randomly from plot.

Marketable yield (kg/ha): is healthy and non-diseased average to large sized Adama Red onion bulbs were recorded from central three harvestable rows.

Unmarketable onion (kg/ha): is split, decayed, diseased and under sized bulbs.

Total bulb yield (kg/ha): is the sum of marketable and unmarketable bulb yields. 
Total biomass yield (kg/ha): this was determined by summation of all above and underground biomass weights of sample plants.

\subsection{Distribution Uniformity of Drip system Installed}

\subsubsection{Emitter flow rate}

The average flow rate of the emitters used in the experiment was measured from plots in which catch cans were randomly assigned plots and volumes of flow caught over a time period. The discharge, or flow rate out of single outlet emitter at a specified head was estimated thus:

\subsubsection{Coefficient of variation $(\mathrm{CV})$ :}

$$
\mathrm{q}=\frac{\mathrm{V}}{\Delta t}
$$

Coefficient of variation was calculated by using the following formula:

\subsubsection{Emitter flow rate variation}

$$
\mathrm{CV}=\frac{\mathrm{s}}{\mathrm{qa}}
$$

Emitter flow rate variation was simply computed as:

\subsubsection{Uniformity coefficient:}

$$
q \operatorname{var}(\%)=100 \frac{(\text { qmax-qmin })}{q \max }
$$

Uniformity coefficient was calculated using the Christiansen coefficient of uniformity formula given as:

$$
\mathrm{UC}(\%)=100\left(1-\frac{\Sigma_{x}}{q^{n}}\right)
$$

\subsubsection{Emission uniformity}

The formula given by Howell and Hiller (1975) cited in Michael (1978) as used to estimate emission uniformity as given by equation:

$$
\mathrm{EU}(\%)=100\left(\frac{\text { qlow quarter }}{\mathrm{q}}\right)
$$

2.6. Water Use Efficiency

Water use efficiency was determined by dividing the harvested bulb yield per unit volume of water used in $\mathrm{kg} \mathrm{ha}^{-1} \mathrm{~mm}^{-1}$.

$$
\begin{aligned}
& \text { CWUE }=\frac{Y}{C W U} \\
& \text { IWUE }=\frac{Y}{I W}
\end{aligned}
$$

Yield Response factor: In order to quantify the effect of water stress on onion, the empirically derived yield response factor (ky) was used and it is the relative yield decrease to relative evapotranspiration deficit using the following equation (12).

$$
1-\frac{\mathrm{Ya}}{\mathrm{Ym}}=\mathrm{Ky}\left[1-\left(\frac{\mathrm{ETa}}{\mathrm{ETc}}\right)\right] \quad \mathrm{OR} \quad K_{y}=\frac{\left(1-\frac{\mathrm{Y}_{\mathrm{a}}}{\mathrm{Y}_{\mathrm{ma}}}\right)}{\left(1-\frac{E T_{a}}{E T_{m}}\right)}
$$

\subsection{Data analysis}

All necessary data collected were managed properly using SAS computer package version 8.2. When the treatments effect was found significant, mean difference was tested using LSD test at $\mathrm{P}=0.05$.

\section{Results and discussion}

\subsection{Distribution Uniformity of the system}

The emitter flow rate and flow rate variation were determined at an operating pressure head of $2 \mathrm{~m}$ at a time using the catch can test method. The measured values of emitter flow rate and flow rate variation were presented. The mean coefficient of variation obtained for the results was $4.90 \%$, indicating relatively low variations of the mean. The measured values of emitter discharge are presented on Table 3.

Based on ASAE (1985) recommendation the field distribution uniformity was excellent, emitter coefficient of variation was good and according to Bralts (1986) emitter flow variation was acceptable. According to Michael (1978) and Jensen (1983 in drip systems, the average variation in discharge rate of individual emitters in a whole field should not exceed $20 \%$. 
Table 3. Uniformity of drip irrigation at experimental site

\begin{tabular}{ccc}
\hline Parameters & Units & Average \\
\hline Emision Uniformities (EU) & $\%$ & 94 \\
Emitter flow variation (qV) & $\%$ & 11.95 \\
Coeffient of variation (CV) & $\%$ & 5.2 \\
Uniformity coeficient (UC) & $\%$ & 95.1 \\
\hline
\end{tabular}

\subsection{Irrigation Water Application in the Experimental Area}

The amount of water applied was based on the daily reference evapotranspiration for the study. The daily reference evapotranspiration was calculated using the FAO-Penman-Monteith method. Soil moisture contents were monitored prior and after irrigation using the gravimetric method from the plots of the all replication (block) throughout the growing season and then these values were converted to volumetric water contents using bulk density. The crop water requirement (ETc) of onion crop was calculated by multiplying the reference evapotranspiration (ETo) with crop coefficient (Kc). The gravimetric soil moisture content revealed that the net total irrigation water determined in $\mathrm{mm}$ for each treatments were through drip irrigation methods at the entire growing period of the crop as it was determined from multiplication of total available water (TAW) and depletion fraction $(\mathrm{p}=0.30)$. The gravimetric soil moisture also revealed that the total gross irrigation water applied in mm to each treatment from all treatments discussed. The total gross depths of irrigation water applied in $\mathrm{mm}$ through drip irrigation methods were varied. The application efficiency of drip irrigation method is taken as $90 \%$ and crop water requirement is taken in $\mathrm{mm} /$ period within five days.

\subsection{Yields and Yield Components 3.3.1. Marketable yield}

Interaction effect of deficit irrigation levels by mulching exhibited a highly significant $(\mathrm{P}<0.01)$ influence on the marketable yield. The highest marketable yield (47.25 ton $\mathrm{ha}^{-1}$ ) was obtained from combined application of treatment received $100 \%$ ETc and plastic mulch whereas the lowest marketable yield $\left(15\right.$ tonha $\left.^{-1}\right)$ was obtained from treatment received 50\% ETc and no mulch. However, there was no significant difference observed in marketable yield among plots treated with 50\% ETc Plastic and straw mulch treatments. For each mulching techniques, marketable yield was decreased with increase in irrigation deficit levels. The trend tended to imply marketable yield was significantly higher as the soil moisture stress decreases. This could be due to the difference in depth of irrigation water applied. The increment of marketable yield as the amount of irrigation levels increased is similar with the (Temesgen et al., 2018) which indicated that yield reduction was associated with increase in soil moisture tension which when allowed continuing resulted in loss of turgidity, cessation of growth and yield reduction.

On the other hand, conducive environment for growth of onion plants maintained by application of plastic mulch followed by plots treated with straw mulch than no mulch along with the increased irrigation levels may have contributed to the production of highest marketable yield. The present finding is in agreement with the results of (Chawla, 2006)) who reported that the highest marketable yield were obtained through black plastic mulch followed by straw mulch (50.02 tons/ha) in tomato crop.

Table 4. Interaction effect of deficit irrigation levels and mulching techniques on marketable yield

\begin{tabular}{lcccccc}
\hline Treatment & \multicolumn{5}{c}{ Marketable Yield (ton ha ${ }^{-1}$ ) } \\
\hline Mulching & $100 \%$ ETc & $80 \%$ ETc & $70 \%$ ETc & $60 \%$ ETc & $50 \%$ ETc & Mean \\
\cline { 2 - 7 } & $40.8^{\mathrm{a}}$ & $33.2^{\mathrm{d}}$ & $30.9^{\mathrm{e}}$ & $25.4^{\mathrm{h}}$ & $20.8^{\mathrm{k}}$ & 30.2 \\
\hline PM & $37.2^{\mathrm{b}}$ & $31.4^{\mathrm{e}}$ & $30.0^{\mathrm{f}}$ & $20.6^{\mathrm{i}}$ & $16.4^{\mathrm{l}}$ & 27.1 \\
SM & $35.7^{\mathrm{c}}$ & $29.9^{\mathrm{f}}$ & $28.4^{\mathrm{g}}$ & $20.0^{\mathrm{j}}$ & $15.0^{\mathrm{m}}$ & 25.8 \\
NM & 37.9 & 31.5 & 29.8 & 22.0 & 17.3 & \\
\hline Mean & 37.9 &
\end{tabular}

a,b,c,d,e, g, g,k,I,m, Mean value followed by the same letters does not differ significantly at p>0.05 probability level, which mean that if the mean value of two yield components have the same letter there is no significant difference among them. 


\subsubsection{Unmarketable Yield}

The analysis of variance showed that interaction effect of deficit irrigation levels and mulching techniques resulted highly significant $(\mathrm{P}<0.01)$ effect on this parameter. The highest unmarketable yield was recorded from plants grown under $100 \%$ and plastic mulch which was about $\left(6.4\right.$ ton $\left.^{-1}\right)$, followed by the treatment that received $100 \%$ ETc and straw mulch. The highest unmarketable yield was recorded from plot that received plastic mulch followed by straw mulch under increased water application levels. The lowest unmarketable dry bulb yield was recorded from plants without mulch. This finding is disagrees by findings of (Stapleton, 2005) who reported that the ability of transparent plastic mulches to produce soil temperatures high enough to control weeds, plant pathogens and nematodes forms the basis for the soil solarisation process and help in reducing amount of unmarketable yield in onion.

Table 5. Interaction effect of deficit irrigation levels and mulching techniques on Unmarketable yield

\begin{tabular}{lcccccc}
\hline Treatment & \multicolumn{5}{c}{ Unmarketable Yield (ton ha ${ }^{-1}$ ) } \\
\hline Mulching & \multicolumn{5}{c}{ Irrigation level } \\
\cline { 2 - 7 } & $100 \%$ ETc & $80 \%$ ETc & $70 \%$ ETc & $60 \%$ ETc & $50 \%$ ETc & Mean \\
\hline PM & $6.4^{\mathrm{a}}$ & $5.8^{\mathrm{d}}$ & $4.5^{\mathrm{g}}$ & $3.6^{\mathrm{i}}$ & $2.7^{\mathrm{l}}$ & 4.5 \\
SM & $6^{\mathrm{b}}$ & $4.9^{\mathrm{e}}$ & $4.2^{\mathrm{h}}$ & $3.4^{\mathrm{j}}$ & $2.5^{\mathrm{m}}$ & 4.2 \\
NM & $5.7^{\mathrm{c}}$ & $4.7^{\mathrm{t}}$ & $2.3^{\mathrm{n}}$ & $3.2^{\mathrm{k}}$ & $2.4^{\mathrm{n}}$ & 3.7 \\
\hline Mean & 6 & 4.9 & 3.7 & 3.4 & 2.6 & \\
\hline
\end{tabular}

a,b,c,d,e, $\mathrm{F}, \mathrm{k}, \mathrm{l}, \mathrm{m}, \mathrm{n}$ Mean value followed by the same letters does not differ significantly at $\mathrm{p}>0.05$ probability level, which mean that if the mean value of two yield components have the same letter there is no significant difference among them.

\subsubsection{Total Yield}

Analysis of variance showed that total yield of Adama onion variety was significantly $(\mathrm{P}<0.01)$ influenced by the interaction effect of deficit irrigation levels and mulching techniques. Accordingly, the maximum total yield (47.25 ton ha $\left.{ }^{-1}\right)$ was obtained from the treatment that received $100 \%$ ETc and plastic mulch, followed by plants that grown mulched with $100 \%$ ETc and straw mulch. The minimum total yields $\left(18.2\right.$ ton $\left.\mathrm{ha}^{-1}\right)$ were recorded at the treatment combination of $50 \%$ ETc and no mulch. High total bulb yield was obtained from high depth of water applied or 100\% ETc under plastic, straw and no mulch respectively and this was significantly different from relatively low depth of water applied treatments 80, 70, 60 and 50\% ETc under plastic, straw and no mulch respectively (Table 6).

For each deficit irrigation level, maximum total yield was obtained from plots treated with plastic mulch which was followed by plots treated with straw mulch than that was obtained from control (no mulch). Accordingly, for each mulching techniques, total yield decreased with increase in the irrigation level deficit. Therefore, yield reduction observed in the treatments that received less depth of water per season could be a result of floral abortion, flower drop, immature bulb drop and reduction in bulb number per plant and consequently total yield reduction due to water stress is also reported by (Bosland and Votava, 2000 and Tasisa, 2018). The observed marked reduction in total bulb yield due to irrigating at 0.5 ETc confirmed the sensitivity of the onion to water stress. Similarly, high floral abortion was observed due to deficit irrigation and partial root drying treatments in an experiment carried out by (Bosland and Votava, 2000) showing the mechanism of bulb yield reduction due to water stress. The significant difference observed among deficit irrigation levels and mulching on total yield of onion in the present study is, therefore, a reflection of the variation in depth of water applied in the respective deficit irrigation levels. The general trend from this result observed that the yield of onion increased with high depth of water supply and decreased with low depth of water supply under different mulching techniques.

Table 6. Interaction effect of deficit irrigation levels and mulching techniques on Total yield of onion

\begin{tabular}{lcccccc}
\hline Treatment & \multicolumn{7}{c}{ Total Yield (ton ha ${ }^{-1}$ ) } \\
\hline Mulching & $100 \%$ ETc & $80 \%$ ETc & $70 \%$ ETc & $60 \%$ ETc & $50 \%$ ETc & Mean \\
\cline { 2 - 7 } & $47.3^{\mathrm{a}}$ & $38.4^{\mathrm{d}}$ & $35.4^{\mathrm{t}}$ & $25.6^{1}$ & $20.7^{1}$ & 33.5 \\
\hline PM & $43.2^{\mathrm{b}}$ & $36.4^{\mathrm{e}}$ & $34.2^{\mathrm{g}}$ & $24.0^{\mathrm{j}}$ & $18.9^{\mathrm{m}}$ & 31.3 \\
SM & $41.4^{\mathrm{c}}$ & $34.6^{\mathrm{g}}$ & $30.7^{\mathrm{h}}$ & $23.2^{\mathrm{k}}$ & $18.2^{\mathrm{n}}$ & 29.6 \\
NM & 43.9 & 36.4 & 33.4 & 24.3 & 19.3 & \\
\hline Mean & $43.4^{\mathrm{n}}$ & & &
\end{tabular}

a,b,c,d,e, g,k,l,m,n Mean value followed by the same letters does not differ significantly at $\mathrm{p}>0.05$ probability level, which mean that if the mean value of two yield components have the same letter there is no significant difference among them. 


\subsection{Yield - Water Relationship}

The relationship between yield (ton $\mathrm{ha}^{-1}$ ) and the depth of irrigation water under different mulching techniques is presented in Table 7. The average yield in study area under deficit irrigation is about 47.25 ton $\mathrm{ha}^{-1}$. One also should notice that treatment received 50\% ETc and no mulch that received $182.4 \mathrm{~mm}$ irrigation water throughout the growing season produced 18.2 ton $\mathrm{ha}^{-1}$. Full irrigation $(100 \%$ ETc under plastic mulch), was used as the reference point for evaluation yield, water saved and relative yield reduction relationship under different deficit irrigation levels and mulching. The data indicated that the highest yield reduction $(61.5 \%)$ was observed under treatment received 50\% ETc and no mulch while, lowest yield reduction is observed under treatment received 100\% ETc and straw mulch. Treatment $60 \%$ and $50 \%$ ETc under plastic, straw and no mulch had shown the highest yield reduction as compared to the other treatments under plastic, straw and no mulch resulted in respectively.

From the result, it can be observed that the yield reduction in treatment received 70\% ETc under plastic mulch is lower as compared to amount of water saved than the other treatments (Table 7). However, applying 60 and 50\% ETc of water under plastic, straw and no mulch significantly decreased the yield. The yield reduction is proportional to the decrease for water applied under different mulching techniques. For instance applying irrigation water $70 \%$ ETc under plastic mulch throughout the whole growing season of onion reduced the yield $12.65 \%$ while water saved $109.5 \mathrm{~mm}$ relative to control treatment. The yield obtained consistently decreased with the decrease for water applied except for 70\% ETc under plastic mulch. Under field conditions, insufficient water supply can adversely affect growth and yield of onion in treatment 50\% ETc than the full irrigation. It was reported that onion were too sensitive to moisture stress and reduced yield significantly at 50\% of water supply (Temesgen et al., 2018 and Dirirsa et al., 2017).

Table 71. Yield, water saved and relative yield reduction relationship under different deficit irrigation levels and mulching.

\begin{tabular}{ccccc}
\hline Treatment & CWU $(\mathrm{mm})$ & TY (ton/ha) & Relative yield reduction & Water saved $(\mathrm{mm})$ \\
\hline T1 & 364.9 & 47.25 & - & 0.0 \\
T2 & 364.9 & 43.17 & 0 & 0.0 \\
T3 & 364.9 & 41.42 & 4.08 & 0.0 \\
T4 & 291.9 & 38.38 & 5.83 & 73.0 \\
T5 & 291.9 & 36.35 & 8.87 & 73.0 \\
T6 & 291.9 & 34.60 & 10.9 & 73.0 \\
T7 & 255.4 & 35.39 & 12.65 & 109.5 \\
T8 & 255.4 & 34.18 & 11.86 & 109.5 \\
T9 & 255.4 & 30.70 & 13.07 & 109.5 \\
T10 & 218.9 & 25.57 & 16.55 & 145.9 \\
T11 & 218.9 & 24.03 & 21.68 & 145.9 \\
T12 & 218.9 & 23.18 & 23.22 & 145.9 \\
T13 & 182.4 & 20.72 & 24.07 & 182.5 \\
T14 & 182.4 & 18.89 & 26.53 & 182.5 \\
T15 & 182.4 & 18.20 & 28.36 & 182.5 \\
\hline
\end{tabular}

\subsection{Crop Water Use Efficiency (CWUE)}

Crop water use efficiency of the onion was significantly $(\mathrm{p}<0.05)$ affected by the interaction effects of deficit irrigation levels and mulching. The interaction of deficit irrigation and mulch showed there were highly significant differences in efficiency values when tested at the 50\% level. At 70\% irrigation water application and plastic mulch, the highest Crop water use efficiencies (CWUE) of $\left(12.75 \mathrm{~kg} \mathrm{ha}^{-1} / \mathrm{mm}\right)$ were obtained. The lowest crop water use efficiency $(9.17 \mathrm{~kg}$ $\mathrm{ha}^{-1} / \mathrm{mm}$ ) was obtained from $50 \%$ irrigation water deficit and no mulch (Table 8). These results show the positive effect of mulch covers even with deficit levels up to $70 \%$ ETc Bare soil (no mulch) was not efficient in conserving water. 
Crop water use efficiency was increasing within the same water application level under the mulching order of no mulch, straw and plastic mulch respectively. Accordingly, maximum crop water use efficiency was recorded from treatment $70 \%$ ETc and plastic mulch $\left(12.75\right.$ ton ha $\left.\mathrm{ha}^{-1} / \mathrm{mm}\right)$ followed by $70 \%$ ETc and straw mulch $\left(8.19 \mathrm{~kg} \mathrm{ha}^{-1} / \mathrm{mm}\right)$ while, the minimum mean crop water use efficiency was observed on $50 \%$ ETc and NM $\left(9.11\right.$ ton $\left.\mathrm{ha}^{-1} / \mathrm{mm}\right)$. There were no significant difference between 100\% ETc SM and 80\% ETc NM, 100\% ETc NM and 50\% ETc PM and also between, $60 \%$ ETc NM and 50\% ETc SM at (p < 0.05) (Table 8). The result of this study indicated that, in the same irrigation water application level in the order of no mulch, straw and plastic mulch respectively resulted a corresponding increasing of mean crop water use efficiency values.

From this result, it is clearly seen that irrigation applied with $70 \%$ ETc under plastic mulch can increases the crop water use efficiency with lower yield reduction. Therefore, when water source is scarce, the onion can be irrigated at the lower water level (70\% ETc) under plastic mulch considering economic conditions.

Table 8. Interaction effect of irrigation levels and mulching techniques on CWUE of onion.

\begin{tabular}{lllllll}
\hline Treatment & \multicolumn{5}{c}{ CWUE $\left(\mathrm{kg} / \mathrm{m}^{3}\right)$} \\
\hline Mulching & Irrigation level & \multicolumn{7}{c}{ Mean } \\
\cline { 2 - 7 } & $100 \%$ ETc & $80 \%$ ETc & $70 \%$ ETc & $60 \%$ ETc & $50 \%$ ETc & Mec \\
\hline PM & $11.9^{\mathrm{c}}$ & $12.01^{\mathrm{bc}}$ & $12.75^{\mathrm{a}}$ & $10.73^{\mathrm{f}}$ & $10.43^{\mathrm{g}}$ & 11.57 \\
SM & $10.8^{\mathrm{ef}}$ & $11.4^{\mathrm{d}}$ & $12.3^{\mathrm{b}}$ & $10.08^{\mathrm{h}}$ & $9.50^{\mathrm{i}}$ & 10.83 \\
NM & $10.4^{\mathrm{g}}$ & $10.89^{\mathrm{f}}$ & $11.04^{\mathrm{e}}$ & $9.74^{\mathrm{i}}$ & $9.17^{\mathrm{j}}$ & 610.26 \\
\hline Mean & 11.06 & 11.46 & 12.02 & 10.2 & 9.7 & \\
\hline
\end{tabular}

a,b,c,d,e,f,g,h,i,j Mean value followed by the same letters does not differ significantly at p $>0.05$ probability level, which mean that if the mean value of two yield components have the same letter there is no significant difference among them.

\subsection{Yield Response Factors (Ky)}

The yield response factor (ky) was derived from the relationship of relative yield reduction $(1-\mathrm{Ya} / \mathrm{Ym})$ and relative evapotranspiration deficits (1-ETa/ETm) for the whole growing period of Onion and are given in Table 9. The result indicates that observed yield response factors (ky) for Adama onion variety Bulb production ranged between 0.88 and 1.40. The lowest yield response factor (0.86) was observed under treatment received 70\% ETc under plastic mulch whereas highest yield response factor (1.40) was observed under the treatment received 80\% ETc irrigation levels and control (no mulch) (Table 9). According to this result deficit irrigations level, 70\% ETc of the full irrigation under plastic mulch in this experiment is therefore useful in saving irrigation water. The higher Ky values indicate that the crop will have a greater yield loss when the crop water requirements are not met. When combined values were used, a ky factor of 1.33 was obtained. Doorenbos and Kassam (1979) reported that Onion yield response factor (ky) would be greater than 1, which corresponded to ky of this study. Under conditions of limited water distributed equally over the total growing season, the crop with $(\mathrm{ky}>1)$ would suffer a greater yield loss than the crop with $(\mathrm{ky}<1)$. This shows that Onion is susceptible horticultural plant to drought stress.

Table 9. Yield response factor for deficit irrigated Onion under mulching.

\begin{tabular}{lllllll}
\hline Treatment & \multicolumn{5}{c}{ Irrigation level } \\
\hline Mulching & \multicolumn{7}{c}{ Ky } \\
\cline { 2 - 7 } & $100 \%$ ETc & $80 \%$ ETc & $70 \%$ ETc & $60 \%$ ETc & $50 \%$ ETc & Mean \\
\hline PM & $0.00^{1}$ & $1.10^{\mathrm{g}}$ & $0.86^{\mathrm{h}}$ & $1.17^{\mathrm{ef}}$ & $1.14^{\mathrm{f}}$ & 0.83 \\
SM & $0.00^{1}$ & $1.21^{\text {cde }}$ & $0.96^{\mathrm{g}}$ & $1.25^{\mathrm{c}}$ & $1.21^{\mathrm{ce}}$ & 0.93 \\
NM & $0.00^{\mathrm{i}}$ & $1.40^{\mathrm{a}}$ & $1.20^{\text {ede }}$ & $1.30^{\mathrm{b}}$ & $1.24^{\mathrm{bcd}}$ & 1.03 \\
\hline Mean & 0.00 & 1.20 & 1.01 & 1.24 & 1.20 &
\end{tabular}

a,b,c,de,f g,h i Mean value followed by the same letters does not differ significantly at p>0.05 probability level, which mean that if the mean value of two yield components have the same letter there is no significant difference among them. 


\section{Conclusion}

This study was aimed at determining the water use efficiency of Onion (Allium cepa L.) under different levels of deficit irrigation practice and mulching techniques and the effects on yield of Onion during which withstand water stress without significant effect on yield. The experimental design of the trial was design in RCBD with three replications.

The results of the experiment revealed that days to $50 \%$ development, days to $50 \%$ maturity, leaf number per plant, mean bulb length were significantly affected $(\mathrm{P}<0.01)$ by the main effects of deficit irrigation levels and mulching but not by the interaction effect of the two. This indicates that recommendation of deficit irrigation and mulching should be done separately for each parameter. However, the interaction effects of deficit irrigation levels and mulching significantly influenced plant height, branch number per plant, bulb number per plant, marketable, unmarketable and total yields of the onion.

There were significant difference between the crop water use efficiency (CWUE) and irrigation water use efficiency (IWUE) due to the interaction effects of deficit irrigation levels and mulching techniques. The highest CWUE and IWUE of 12.75 and $7.63 \mathrm{~kg} \mathrm{ha}^{-1} \mathrm{~mm}^{-1}$ was obtained from irrigation water application $70 \%$ ETc and plastic mulch while the lowest CWUE and IWUE of 9.17 and $5.49 \mathrm{~kg} \mathrm{ha}^{-1} \mathrm{~mm}^{-1}$ was recorded under $50 \%$ water deficit and no mulch. With $70 \%$ ETc and plastic mulch the water saved, yield reduction and CWUE were $109.5 \mathrm{~mm}, 12.65 \%$ and $12.75 \mathrm{~kg} \mathrm{ha}^{-1} \mathrm{~mm}^{-1}$, respectively. Considering the highest water saving and maximum onion yield, irrigation water application at $70 \%$ irrigation application levels and plastic mulch could be considered as optimal irrigation management as compared to other deficit treatments. Observed yield response factors (ky) for Onion Bulb production ranged between 0.86 and 1.40, the lowest and highest being for 70\% ETC water application level under plastic and 80\% ETc applications under no mulch, respectively.

Generally, results from the present level of work confirmed that there exists a relative delay in maturity, increased plant height, branch number, marketable bulb yield, total bulb yield and higher water utilization efficiency due to decrease in deficit irrigation levels. This results show that combining different irrigation levels with use of mulch covers, particularly straw mulch that is in abundance with farmers, presents a sustainable strategy for onion production in the water scarcity areas of Ethiopia. Use of plastic mulches laying difficulties with these materials in windy conditions presents challenges to farmers. Imposing irrigation deficit levels beyond 50\% is not advisable as marketable yields and mean bulb length decline. The drip system technology used in the study is at entry level for farmers and it is apply demonstrated from the work that the amount of water savings that can be achieved is substantial when compared to other irrigation systems.

\section{Reference}

[1] Aklilu Masfin. 2009. Effect of mulching and depth of irrigation application on water use efficiency and productivity of pepper under gravity drip irrigation. MSc Thesis, Haramaya Uni versity.

[2] Ali, M.H, 2010. Fundamentals of Irrigation and On-farm Water Management. Springer Science and Business Media, New York United States of America.pp.583.

[3] Awulachew, B., D. Aster, L. Makonnen, L. Willibald, Mekonnen, A. and Tena, A. 2007. Water Resources and Irrigation Development in Ethiopia. International Water Management Institute. (Working Paper 123). Colombo, Sri Lanka.

[4] Bosland, P.W. and Votava, E.J. 2000. Pepper: Vegetable and Spice Capsicums. CABI Publishing, New York.

[5] Bralts, V. F. 1986. Operational principles-field performance and evaluation. In: Trickle Irrigation for Crop Production, Amsterdam, Elseiver, pp. 216-240.

[6] Chawla, S. L. 2006. Effect of irrigation regimes and mulching on vegetative growth, quality and yield of flowers of African marigold. Ph.D. Thesis, Department of Horticulture, Maharana Pratap Uni versity of Agriculture and Technology, Udaipur.

[7] Dirirsa, G., Woldemichael, A. and Hordofa, T. 2017. Effect of deficit irrigation at different growth stages on Onion (Allium cepa L.) production and water productivity at Melkassa, Central Rift valley of Ethiopia. Acad. Resource Journal Agriculture Science. Resource. 5(5): 358-365

[8] Dorji, K., Behboudian, M. H. and Zegbe-Dominguez, J. A. 2005. Water relations, growth, yield, and bulb quality of hot pepper under deficit irrigation and partial root zone drying, Science Horticulture, 104: 137-149.

[9] FAO (Food and Agricultural Organization) 2012. Crop Evapotranspiration (Guidelines for computing crop water requirement). Irrigation and Drainage, 56:163.

[10] Goreta S., Perica, S., Dumicic, G., Bucan, L. and Zanic, K. 2005. Growth and yield of water melon on polyethylene 
mulch with different spacing and nitrogen rates. Journal of Horticultural Science, 40, 366-369.

[11] Habtie Honelign. 2007. Comparison of different Irrigation Scheduling Methods for Tomato (Lycopersicum esculentum L.) Production in Libokemkem Woreda south Gondar Zone. MSc Thesis, Haramaya Uni versity.

[12] Heidari, H. 2012. Alternate Furrow Irrigation Effect on Yield, Yield Components and Seed

[13] Germination of Foxtail Millet (Setaria Italica) In Double Cropping System. International Research Journal of Applied and Basic Sciences. 3(1): 64-69.

[14] Hillel, D. 2004. Introduction to Soil Environmental Physics. University of Massachusetts, Elsevier Academic Press. New York.

[15] Mokenon Ayana. 2011. Deficit irrigation practices as alternative means of improving water use efficiencies in irrigated agriculture: A study of maize crop at Arba Minch, Ethiopia. African Journal of Agricultural Research, 6(2): 226-235.

[16] Nigatu, A.W. 2008. Identification of the critical water requiring growth stage on Onion (Allium cepa L.) for bulb production in the Central Rift Valley. MSc. Thesis. Haramaya Uni versity, Ethiopia.

[17] Smith, R. 2011. Fresh onion bulb production in California. Agricultural and Natural Resources Communication Service, 13: $987-10$

[18] Steduto P., C. Hsiao, Dirk Raes, and Elias Fereres. 2009. The FAO Crop Model to Simulate Yield Response to Water. Agronomy Journal. 101 (3):426-437.

[19] Tasisa Temesgen. 2017. Effect of Deficit Irrigation on Yield and Water Productivity of Furrow Irrigated Onion (Allium Cepa L.) in Ambo, Western Ethiopia. MSc Thesis, Haramaya Uni versity.

[20] Temesgen T, Ayana M and Bedadi B. 2018. Evaluating the Effects of Deficit Irrigation on Yield and Water Productivity of Furrow Irrigated Onion (Allium cepa L.) in Ambo, Western Ethiopia. Journal of Irrigation Drainage System Engineering 7: 203.

[21] Tilahun, H., Yusuf, K., and Mesfine, M. 2004. Response of tomato to different irrigation schedules under Melkassa conditions. pp 202-203. Kibebew, A. and Lijalem, K. (eds) 2006. Proceedings of the Tewelfth Annual Conference of the Crop Science Society of Ethiopia. Addis Ababa, Ethiopia. 